\title{
Talent identification and location: A configurational approach to talent pools
}

\author{
Maria Carmen De La Calle-Duran ${ }^{1}$ (D), Maria de la Luz Fernandez-Alles ${ }^{2}$ (iD, \\ Ramon Valle-Cabrera ${ }^{3}$ (iD) \\ ${ }^{1}$ Universidad Rey Juan Carlos (Spain) \\ ${ }^{2}$ Universidad de Cadiz (Spain) \\ ${ }^{3}$ Universidad Pablo de Olavide (Spain) \\ carmen.delacalle@urjc.es,mariluz:fernandez@uca.es,rvalcab@upo.es
}

Received April, 2019

Accepted May, 2021

\begin{abstract}
Purpose: Talent management (TM) has become a strategic priority for companies seeking to identify employees with outstanding performances and the potential to hold strategic positions in the future. In fact, talent is considered an intangible capital that adds value to the organisation. However, there are only a handful of studies in the literature that address the process of identifying talent in organisations for its subsequent development. Thus, the purpose of this paper is to reach a better understanding of the process of identifying and locating talent, while proposing a configurational approach as a theoretical framework for grouping talented individuals into different configurations or talent pools to initiate talent development in firms.
\end{abstract}

Design/methodology: Case study methodology research based on four companies that have implemented TM programmes in Spain.

Findings: The research questions formulated here and the case studies shed light on the process of identifying talent and on the criteria for grouping it in order to facilitate its future development. Our results highlight the following. First, talent means people with certain characteristics. Second, companies focus more on developing the talent identified than on considering the innate nature of that talent. Finally, talent can be found throughout an organisation, in both management and non-management positions. In turn, we conclude with the relevant theoretical contribution of the configurational approach to explain that a company's future competitive advantage is based on the different talent pools existing in its organisation that group talent for its differential management.

Practical implications: Our results imply major recommendations for companies on how to identify talent and group it into talent pools in order to implement a process of differentiated management involving a range of temporal pathways.

Originality/value: The identification and location of talent, as well as grouping it into talent pools, is an essential prior process for proposing the talent architecture that is so much in demand in the literature.

Keywords: Talent, Talent management, Talent pool, Configurational approach 
Jel Codes: M12

\section{To cite this article}

De La Calle-Duran, M.C., Fernandez-Alles, M.L., \& Valle-Cabrera, R. (2021). Talent identification and location: A configurational approach to talent pools. Intangible Capital, 17(1), 17-32.

https://doi.org/10.3926/ic.1440

\section{Introduction}

The importance of talent and its management is highlighted both for companies and for the academic field. There are numerous reports (Deloitte, 2015; BCG, 2018) contending that Talent Management (TM) in an organisational context is currently a priority issue for companies, as it can be a source of competitive advantages in their dynamic and competitive environments, providing strategic opportunities, and creating value (Lewis \& Heckman, 2006; Collings \& Mellahi, 2009, Farndale, Scullion \& Sparrow, 2010; Schuler, Jackson \& Tarique, 2011; Meyers \& van Woerkom, 2014; Makram, Sparrow \& Greasley, 2017; Shulga \& Busser, 2019; Sparrow, 2019). In the academic field, the relevance of talent and its management is also highlighted in literature reviews through bibliometric analyses carried out by Iles, Preece and Chuai (2010b), Gallardo-Gallardo, Nijs, Dries and Gallo (2015), Gallardo-Gallardo and Thunnissen (2016) and McDonnell, Collings, Mellahi and Schuler (2017), which provide increasing evidence of the popularity of the research topic.

Given the increasing interest for companies and the higher scientific output on the issue, it may be assumed that TM constitutes a well-defined area of research, supported by extensive empirical research and a strong theoretical background. However, this is not the case, empirical works are still needed to clarify ambiguous aspects of talent and its management (Lewis \& Heckman, 2006; Collings \& Mellahi, 2009; Silzer \& Church, 2009; Gallardo-Gallardo, Dries \& González-Cruz, 2013; Meyers, Van Woerkom \& Dries, 2013; Thunnissen, Boselie \& Fruytier, 2013a; Al Ariss, Cascio \& Paauwe, 2014; Collings, Scullion \& Vaiman, 2015; Gallardo-Gallardo \& Thunnissen, 2016). In addition, there is no consistent theoretical framework (Lewis \& Heckman, 2006; Dries, 2013; Gallardo-Gallardo et al., 2013; Alonso \& Garcia-Muiña, 2014; Meyers \& van Woerkom, 2014). Therefore, certain articles conclude that TM research is still in its infancy (Thunnissen et al., 2013a) and must face the challenge of developing into a greater state of maturity (Collings et al., 2015; Gallardo et al., 2015).

Further progress in the field of TM calls for studies on the following: (i) clarifying several aspects related to TM that are still imprecise (Thunnissen \& Van Arensbergen, 2015; Gallardo-Gallardo \& Thunnissen, 2016; Sparrow, 2019; Shulga \& Busser, 2019), as despite abundant prior research on the definition of talent (Gallardo-Gallardo et al., 2013) and its operationalization (Nijs, Gallardo-Gallardo, Dries \& Sels, 2014), there are still few studies on talent identification and location; (ii) the application of theoretical approaches such as the configurational one, which while arguably increasing the fragmentation of TM research (Sparrow, 2019) would also help to explain the process of identifying talent and grouping it into talent pools. Prior studies have already reported the existence of talent groupings (Björkman \& Smale, 2010; Mäkelä, Björkman \& Ehrnrooth, 2010), albeit without a theoretical grounding that explains the way of classifying these talented employees (Thunnissen \& GallardoGallardo, 2019), and (iii) new empirical evidence within a Spanish context, where prior research has indeed already been conducted (Vivas-López, Peris-Ortiz \& Rueda-Armengot, 2011; Valverde, Scullion \& Ryan, 2013; Vivas-López, 2014; Maqueira, Bruque \& Uhrin, 2019), although there are only a handful of practical studies on how firms address the talent identification and grouping process.

Considering these antecedents, the objective of the study is to identify and locate talent in organisations and propose a configurational approach as the theoretical framework for grouping it into different talent pools for the application of a differentiated talent management process to each one of them. The identification of talent involves answering four research questions, which according to the literature (Collings \& Mellahi, 2009; Iles, Chuai \& Preece, 2010a; Gallardo-Gallardo et al., 2013; Meyers et al., 2013; Ross, 2013; Nijs et al., 2014) allow reflecting upon how talent is identified and where it is located. Subsequently, based on a study case methodology, 
this paper analyses four cases of companies operating in Spain that implement TM, deriving theoretical propositions based on our findings. The results conclude that the talent is located in three pool configurations that constitute the bases for the development of an architecture of TM that is being demanded in the literature (Ganz, 2006; Garavan, Carbery \& Rock, 2012; Sparrow \& Makram, 2015).

\section{Talent identification and location}

Certain studies in the literature have made a greater effort to shed light on conceptualising talent as an essential prior step to effective TM (Tansley, 2011; Gallardo-Gallardo et al., 2013; Meyers et al., 2013; Ross, 2013). However, there is still ambiguity over identifying talent in organisations. Along these lines, Nilsson and Ellström (2012) suggest the need to clarify certain aspects relating to the identification and location of talent because, as affirmed by Nijs et al. (2014:180) "Organizations report great difficulty in measuring talent accurately, reflecting the lack of theoretical foundations for talent-identification in the HRM literature."

We have therefore included four apparently opposing questions to be answered through the literature review (Collings \& Mellahi, 2009; Iles et al., 2010a; Gallardo-Gallardo et al., 2013; Meyers et al., 2013; Ross, 2013; Nijs et al., 2014). The first two aim to explain how to identify talent and the other two where to locate it. How and where are key issues prior to the implementation of TM.

\subsection{Talent: People or characteristics of people?}

Two different approaches have been used to conceptualise talent - an object one and a subject one - which according to Gallardo-Gallardo et al. (2013) co-exist in the literature, but are somewhat contradictory. According to object approach, talent is defined as characteristics of people. This approach is supported by authors that consider talent to be an exceptional characteristics of people, in which certain studies include capacity, knowledge, ability, potential, skills, and performance (Tansley, Turner, Carley, Harris, Sempik \& Stewart, 2007; Cheese, Thomas \& Craig, 2008; Chuai, Preece \& Iles, 2008; Silzer \& Dowell, 2010; Stahl et al., 2012; GallardoGallardo et al., 2013). In light of the myriad definitions we find under this approach, it is particularly interesting to identify the components of talent. For Gallardo-Gallardo et al. (2013) and Nijs et al. (2014), although the possession of special capacity, ability or skills is necessary to have talent, it is nevertheless insufficient. These authors consider the presence of non-intellectual attributes relating to affectivity to be necessary, such as commitment, according to Gallardo-Gallardo et al. (2013), and interest and motivation, according to Nijs et al. (2014). These authors consider the affective component of talent to be the result of adding the motivation and interest that makes people work with "passion".

According to the subject approach supported by Gallardo-Gallardo et al. (2013), talent is considered to be people; in other words, employees with special abilities and capacity that are reflected in high levels of performance and potential. Under this approach, Lewis and Heckman, (2006:141) refer to "talent as a euphemism of people". Tansley et al. (2007:8) in Gallardo-Gallardo et al., (2013:295) define talent as "those individuals who can make a difference to organizational performance, either through their immediate contribution or in the longer-term by demonstrating the highest levels of potential".

\subsection{Talent: Innate or developed?}

Some definitions of talent, such as that by Silzer and Dowell (2010:14), which refers to "an individual's skills and abilities (talents) and what the person is capable of doing or contributing to the organization" open the debate as to whether talent is innate or the result of a learning process that enables its creation and development. As part of the debate, Meyers et al. (2013) propose a continuum in which they consider three possible situations. The first considers talent to be totally innate, meaning there are people with the same training that always perform better than others because they possess certain unique and profound characteristics that cannot be learned (Gallardo-Gallardo et al., 2013). 
The second considers that talent is partly innate and partly developed. The authors that support this approach believe that innate talent is a necessary but insufficient condition to attain a high performance, and assume that there is a component of talent that is acquired.

The third, in which talent is defined as the result of a learning process, concludes that anyone can be a prodigy. In this situation, talent is seen as the result of a deliberate practice, effort, training, development and learning process based on experience, meaning that anyone can necessarily have to be the top positions, and may be at an operational level. be talented (Collings and Mellahi, 2013; Gallardo-Gallardo et al., 2013; Meyers et al., 2013).

\subsection{Talent: People or positions?}

This second question is to determine whether talent involves those people with a high performance and potential, who can make a significant contribution to the organisation's future performance without being linked. Iles et al. (2010a) propose two approaches to TM: one exclusively based on people, and the other exclusively based on their position or job. The first approach involves a narrow view of TM based on the management of a limited group of people, a talent pool, with greater achievement and the capacity to make a significant difference in the organisation's present and future performance. Under this consideration, talent is not related to the position held by an employee. On the contrary, the approach based on the position considers talent to reside in the key positions within the organisation; in other words, in positions with a strategic value, whereby only employees that hold such positions can be classified as talent (Huselid, Beatty \& Becker, 2005). Collings and Mellahi (2009) also support this approach, and define key positions as those that can potentially affect the future of the company, have strategic value with respect to the company's competitive advantage, and do not

\subsection{Talent: Only the elite or throughout the organisation?}

One of the key issues in TM and its definition is to locate talent. There are two approaches used in the literature: an inclusive and an exclusive one. Under the inclusive approach, everyone in the organisation has talent, any employee can be considered as a strategic asset capable of generating value and achieving a competitive advantage, and should therefore be given the opportunity to demonstrate and develop it (Iles et al., 2010a; Stahl et al., 2012; Gallardo-Gallardo et al., 2013). By contrast, the exclusive approach is based on a segmentation or differentiation of the workforce, and under this approach it is not possible to be considered talent in the organisation. Talent resides only in a certain elite group within the organisation and comprises the talent pool (Boudreau \& Ramstad, 2005; Collings \& Mellahi, 2009; Iles et al., 2010a; Gallardo-Gallardo et al., 2013). According to the exclusive approach, talent resides in employees with a high performance and potential. In turn, these employees must contribute significantly to achieving organisational objectives by means of an aboveaverage performance (Silzer \& Dowell, 2010; Stahl et al., 2012; Meyers et al., 2013). However, this is not sufficient, and must include other characteristics, such as experience, creativity, leadership, and attitude (Tansley, 2011; Dries, Van Acker \& Verbruggen, 2012), which make up potential. Potential is defined as the capacity to progress and learn more quickly, and results in the ability to adjust to the company's future needs. For Tansley (2011), potential is related to an individual's ability to progress towards more senior roles and leadership positions, which she specifically defines as "someone with the ability, engagement and aspiration to rise to and succeed in more senior, more critical positions" (p. 272). According to Silzer and Church (2009), potential is rarely used in relation to current work performance, but is typically used to suggest that an individual has the qualities to effectively perform and contribute in broader or different roles in the organisation at some point in the future.

Based on these four questions, in the following section we use a case study methodology to clarify how to identify, locate, and group talent for its subsequent development. 


\section{Methodology}

\subsection{Case study as the research methodology}

The methodology used to conduct this empirical research was the case study method (Yin, 1994). The reasons that justify the relevance and choice of this method are twofold. Firstly, the consideration of the research issues in terms of how and why, given that the current corporate context gives rise to the need to analyse why TM should be studied and how talent is located and grouped, which requires its prior identification. Secondly, according to Eisenhardt (1989), the case study methodology is recommendable for issues that are new, especially if the intention is to progress theoretically, as in the case of TM, which is defined as a discipline in its adolescence (Thunnissen et al., 2013a) and still growing (Collings et al., 2015; Gallardo et al., 2015).

The research can be classified as follows: firstly, it is explanatory by nature, as it seeks to find empirical evidence for the theoretical development of the debate based on the research issues raised and according to the conceptual framework obtained from a literature review, by deducing and defining a series of propositions within the new concept of talent pools as differentiated configurations. Secondly, with regard to the sample, this case study specifically involves four companies. The choice of a single case was not recommendable here, as it is not valid for generalisations and would be limited to a descriptive study of the organisation in question, with greater bias in the conclusions. We increased external validity and reduced bias by carrying out a pilot case study, and decided to replicate the research process in three other organisations, according to the recommendations of Eisenhardt (1989) that four is a suitable number. Thirdly, the criterion for using a case study method is to generate theory in the absence of a sound theoretical framework for TM research (Lewis \& Heckman, 2006; Gallardo-Gallardo et al., 2013; Thunnissen, Boselie \& Fruytier, 2013b; Al Ariss et al., 2014). According to this last criterion, our research is structured as a case study of a holistic nature (Yin, 1994), in which the unit of analysis is represented by the companies that have implemented a TM plan, and the level of analysis is determined in relation to human resources management strategy.

\subsection{Sample and data collection}

We used theoretical sampling to identify the selection of cases. To facilitate the data collection process, four companies were selected from different industries that have implemented TM in Spain: Hospitality (Case A), Telecommunications (Case B), Aerospace (Case C), and Infrastructures and services (Case D). We have conducted a pilot study in Case A, and decided to replicate the research process in another three cases until we reached information saturation. Regarding Case A, the general manager facilitated access to two key persons in TM implementation: the corporate HR director and a specialist in the field of TM.

In order to replicate the investigation in the other three cases, the corporate HR directors were contacted, inviting them to participate in the research. All the companies agreed to participate at an initial meeting in which they were briefed on the project. At the same time, they identified the key people that could outline contextual issues within their organisations and advise us regarding further data collection. Specifically, five more people were interviewed: the HR manager and a TM specialist in Case B, the TM manager in Case C, and the corporate HR director and the talent development manager of a business unit in Case D. More than one informant was therefore interviewed in three of the four cases, so we reduced the bias in the answers obtained. In Case C, the importance of the person interviewed rendered it unnecessary to include anyone else in the investigation. Data collection involved the analysis of numerous internal documents, some of which were very valuable because they are TM-specific, but also strategy documents, archival data in the form of annual reports, internal company magazine articles, and websites, as well as external documents, such as specialised publications, reports by outside organisations, and articles published in the media, in some cases by the key informants interviewed.

An interview protocol was subsequently developed, and an interview template was designed to obtain insights involving questions on a number of issues, including the implementation of TM, the talent identification and location and the practices developed in each one of them for different groups of employees. Fourteen face-toface semi-structured and in-depth qualitative interviews were held with the seven key people mentioned above, 
some of whom were interviewed more than once. During the interviews, respondents were encouraged to describe and share information about their experiences both in relation to company strategies and their involvement in TM processes. The interviews, which on average lasted 90 minutes, were recorded for subsequent transcription, translation, and analysis.

Finally, two questionnaires were designed: the first one was an eight-part questionnaire covering the following aspects: identification of the company and the respondent, general information regarding the implementation of TM, talent definition and identification, and talent development. The questionnaire was made up of 16 open questions, five dichotomous questions, 10 categorical questions with response options, and three closed questions of between 6 and 12 items each, measured on a five-point Likert scale. The second one, based on the information obtained in the interviews and the Chami-Malaeb and Garavan index (2013), was used to determine TM scale practices in each talent pool. This questionnaire was emailed to 15 people considered specialists in TM. As in the work by Chami-Malaeb and Garavan (2013), analyses were performed to rule out possible multicollinearity, and then a factorial was made to ensure that each group of practices was applied for each talent pool and for different objectives.

\subsection{Data analysis}

The data analysis involved the free software VosViewer (version 1.6.5.). This provides easy-to-use softwareassisted qualitative data analysis focusing on the visualisation of bibliometric networks, although it is also used for qualitative content analysis. This tool creates a map based on text data, specifically creating term cooccurrence. The advantage of using qualitative content analysis software is that it allows for transparency, speed of data processing, and a reduction in the amount of data required for their analysis and objective interpretation. Term maps can be created directly based on a text corpus, so the interviews were transcribed, translated into English, revised to correct possible errors, and saved in "plain text" format. Subsequently, for all the interviews in each one of the cases, data analysis allowed identifying clusters that collected keywords that we could relate to some of the research questions.

\section{Findings}

The purpose of this work is to identify and locate talent in organisations and propose a theoretical approach to the grouping of talent for its subsequent differentiated development. The findings and ensuing discussion are arranged into two sections: the identification and location of talent, and the proposed configurational approach for its grouping.

\subsection{Talent identification and location}

The findings related to talent identification and location are articulated around the four questions raised in section 2 .

As regards the issue of whether talent involves people or their personal characteristics, we have found evidence in the four cases analysed to show that these two approaches are not mutually exclusive, but instead complement each other in order to identify and locate talent. In the four cases studied, this means that talent is located in certain individuals, with the most recurrent terms being "people" in Case A, "individuals" in Case B, and "future leaders" in Case C. In the opinion of the companies subject to the study, it is pointless to identify talent if it is not personified in the individuals shown to possess it. Furthermore, our findings show that talented individuals have certain shared personal characteristics that are defined in the cases as: high levels of performance within the company (Cases A, B, C, and D) or outside the company (Case C), values that are coherent with those of the company, commitment, and the desire to grow (Case A), ability to learn quickly (Case B), mobility (Cases A and C), skills (Case D), and potential (Cases A and C).

The definitions of talent we have found in the four cases all confirm the importance of the aforementioned characteristics for talent identification. Thus, in an internal document kept by Case A (Talent Management. Boost your potential), we found talent defined as "an individual that possesses three characteristics: proven higher 
performance, a profile that is in line with the ethics and values of the group and the desire to develop personally and professionally within such group". Case B, also in an internal document: Development Conference Guideline defined talent as "the future leaders and therefore the employees that are potentially capable of holding strategic management positions with key functions". In a specific internal TM document: Future Leaders, Case C defined talent as "an employee with the potential to take on a leadership position with the group in the future". Finally, the key respondents in Case D (corporate HR director and talent development manager) when interviewed defined talent as "an individual with the capacity to learn faster and the ability to successfully apply such knowledge to new situations".

The presence of these characteristics in employees is often measured using certain talent identification practices over and above traditional performance assessment measures that also cater for the appraisal of potential, such as $360^{\circ}$ feedback (Cases B and D) and the assessment centre (Cases A and C).

As to whether talent is innate or developed, our results showed that those responsible for talent assume there is an innate part of talent. What truly maters for companies is its development. Accordingly, the talent managers in Case B affirm: "We do not analyse how an employee has acquired talent, what interests us is how they develop their current talent and future potential. Our goal is to find the best tools for developing talent". The HR manager in Case C adds "We are not interested in whether there is an innate part of talent. We are interested in that part that can be developed". In all the cases analysed, talent is identified by its ability to develop the characteristics identified in the preceding section, and these people are located in part by their scope for personal and professional development (Case A), the development of potential (Cases B and C), and future learning (Case D). The results therefore reveal the importance in all four cases of the scope for development, growth and learning among those employees identified as talent.

In this respect, the Director of the HR Corporate Development Department in Case D stated in an article published in the company's blog that "talent is both the capacity to learn faster, as well as the ability to successfully apply what is learned to new situations. In short, it is basically the greater capacity to successfully adapt to change; not to be prepared for a particular scenario, but rather to be prepared to profit from any possible scenario".

The development practices identified in the cases explain how important it is that these employees identified as talent should grow through coaching or training programmes or via mobility either within the company or internationally, and specifically that the development of talent is achieved with tools such as executive coaching (Cases A, B and C), events of visibility and exposure (Case A), assignation to international projects (Case D) and premium training, especially for top management positions (Cases $A$ and $C$ ). For mid-management, mentoring (Cases A and C), rotation (Case D) and training in skills (Cases A, B and C) are particularly suitable. Finally, for non-executive positions, group mentoring, rotation and technical training constitute key tools for developing talent.

As regards talent: people or positions, regardless of the fact that in certain cases, such as Case C, TM is being developed exclusively for executive positions for budgetary reasons, in all our cases, TM focused on the talented employee. In the opinion of the HR Manager in Case A: "belonging to the talent pool does not depend on the position held by an individual, but rather the person him or herself". Similar terms were used by the Head of Training and Development in Case A: "people do not belong to the talent pool because of the position they hold, but because of their performance and potential'. In Case B, the process of identifying talent is based on an assignment of people, irrespective of the position they hold. In Case C, the identification of talent is the result of an analysis of the people that show potential and performance. Finally, in Case D, the Head of HR Development stated that "TM is a specific model for a group of people that have been highlighted". According to the HR Manager, "the identification of the members of the talent pool is based on a process of people being assigned by any company employee. Subsequently, the people identified are evaluated at a roundtable discussion, to effectively determine whether or not they can be considered as talent".

In Case D, talent is considered at a corporate level as people holding operating positions, as well as midmanagement and top executive positions. It should be pointed out that at a business unit level, Case D has focused on implementing TM only for employees that hold management positions, as in the cases of A and C. 
As regards talent: only the elite or throughout the organisation, consistent with the prior results the findings show that talented employees are identified according to certain characteristics, regardless of the position they hold and whether or not they belong to an executive position. In this sense, the Head of HRM in Case D stated that: "In our sector, there is a highly sought-after profile of individuals: topographers that have still not held management positions are vital for achieving competitive advantages. It is essential for our company to develop this talent". In turn, the HR Director in Case A affirms: "Talent at our company may be found anywhere in the organisation. Our challenge is to identify it in order to develop it and ensure these individuals hold key position in the future". In this respect, the Director of the HR Corporate Development Department in Case D stated in an article published on the company's blog that "talent is both the capacity to learn faster, as well as the ability to successfully apply what is learned to new situations. In short, it is basically the greater capacity to successfully adapt to change; not to be prepared for a particular scenario, but rather to be prepared to profit from any possible scenario. And so indeed, it may be found anywhere in the organisation".

\subsection{Configurational approach to grouping talent into Talent Pools for its subsequent development}

Once talent has been identified, it needs to be located and grouped to continue the development process.

The different timelines in which individuals can develop their talent is a criterion that allows talent to be grouped. In our cases, we have found similarities in the way of grouping talent, and in the four cases we have identified three kinds of talent pools (Figure 1).

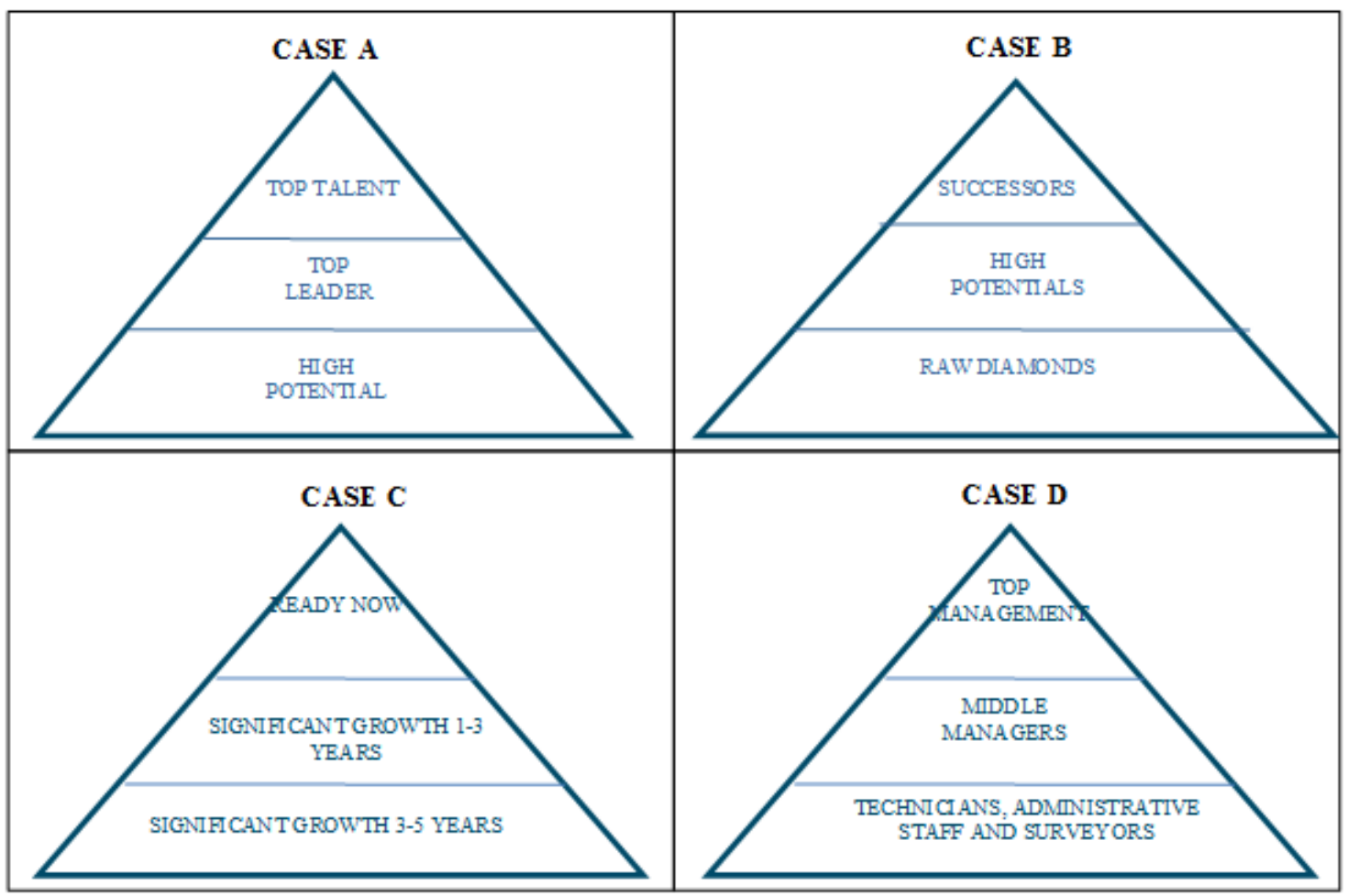

Figure 1. Talent pool configurations in the case studies

Figure 1 shows that Talent pool 1 is comprised of top managers which would develop and hold future strategic management positions more quickly. In Case A, they are called "top talent", in Case B "successors", in Case C "ready now", and in Case D "top management". Talent pool 2, with longer-term development over a greater period of time, could form part of Talent pool 1 through a process of TM and hold strategic management positions in the future. In the cases analysed, this talent pool was called "top leaders" in Case A, "high potentials" in Case B, "significant growth within 1-3 years" in Case C, and "mid-management" in Case D. Talent pool 3 is comprised of people with talent that do not hold management positions with the company, although 
they do hold key positions, meaning that the identification of talent is essential for the company to have its talent located for future development, to avoid it leaving, and to guarantee the succession of management positions.

The TM objective in this talent pool would be to locate this talent, as such persons do not hold management positions, and the talent could therefore be spread throughout the organisation. In the cases subject to analysis, this talent pool was called "high potential" in Case A, "raw diamonds" in Case B, "significant growth within 3-5 years" in Case C, and "technicians, clerks and topographers" in Case D.

\section{Discussion}

The discussion is articulated around talent identification and location, on the one hand, and its grouping, on the other.

\subsection{How to identify and locate talent}

As regards the process of identifying and locating talent, we may reach four conclusions,

First, we can conclude that identifying talent requires locating those individuals with certain characteristics such as knowledge and skills, as well as certain attitudes, such as commitment and leadership, learning ability, and attitude and motivation that confirm their performance and potential. Therefore, the dilemma as to whether talent is the skills or the person is resolved when the companies define what they consider as talent within the context of their strategies, and subsequently identify the employees that meet the required conditions.

According to the evidence, all these definitions reveal that the companies analysed consider talent to be the individuals, people or employees that possess a series of features that set them apart or make them different from other employees, meaning that both approaches to talent (Gallardo-Gallardo et al., 2013) - the objective one (talent as personal characteristics) and the subjective one (talent as certain people) - are appropriate for its identification.

To identify the presence of these features in people, it is necessary to address two dimensions of talent: within the former, we may distinguish between intellectual attributes, which include capacity, skills and abilities, and affective attributes, values, commitment, attitude, and motivation. this is in line with the two components of talent: ability and affective, reported by Nijs et al. (2014). One refers to the nature of these characteristics in talented individuals, and the other involves the temporal dimension of those characteristics. In turn, there is a need to differentiate between talent's current and future dimensions. On the one hand, talent has a current dimension, high performance, which is measured by the actual contribution an individual makes, and has made in the past, in terms of performance, and constitutes an indicator of an employee's future performance, meaning that their past experience is vital (Garavan et al., 2012). This allows differentiating talent that "can be operationalized as performing better than others or performing consistently at one's personal best" (Nijs et al., 2014: 182). On the other hand, talent also has a future dimension, potential, which is measured by an individual's future capacity to adapt to the company's strategic needs, to learn and progress, which materialises in higher levels of performance in the future. Talent's potential includes an employee's commitment and attitude in relation to growing rapidly and progressing within the company, and has a multiplying effect on future performance, in line with authors such as Chuai et al. (2008). Therefore, based on our evidence and the work of Silzer and Church (2009), Tansley (2011) and Dries et al. (2012), talent's differentiating features are therefore as follows: besides knowledge, skills and high performance, the capacity to grow, learn, advance, progress and develop quickly to improve, face new challenges, apply what has been learned, influence the company (ambition), and be flexible in light of the company's future needs (commitment).

Second, once talent has been identified and located, the main thing is to focus on developing the part that can be acquired and developed, rather than analysing which part is innate. Our results are more in line with the second approach of Meyers et al. (2013), which claims that there is an innate part and another part susceptible to development. As posited by Silzer and Dowell (2010), we found that the companies here focused on taking a pragmatic approach to talent, without differentiating between its innate or developed components. 
The companies' remit is to focus on the component of talent that can be developed by means of personal growth based on relations, working experience, and training (Garavan et al., 2012). The practices for developing the talent identified in the cases here are some of those defined by Garavan et al. (2012), and they differ according to the talent configuration or groups being considered.

Third, it is not the position in a specific job that informs the inclusion in a talent pool, but instead the presence of certain characteristics in specific individuals. This means that talented individuals may not be in management posts and irrespective of the position they hold, supporting the approach based on people as opposed to their positions, as maintained by Collings and Mellahi (2009).

Finally, we may conclude that although TM focuses on a differentiated group of talented individuals, these people might be anywhere in the company, with companies adopting what scholars refer to as an exclusive talent approach (Iles et al., 2010a; Gallardo-Gallardo et al., 2013). TM focuses on an elite group of employees; however, such employees with the aforementioned characteristics can be found anywhere in the organisation.

Based on the above, we establish the following proposition for identifying talent (Figure 2):

Proposition 1. Talent identification is based on identifying those individuals, with a management position or not, that have high levels of current performance and future potential, as a result of a combination of intellectual attributes (capacity, knowledge, skills and abilities) and affective ones (commitment, attitude, and motivation) that can be developed in order to guarantee strategic company positions in the future.



Figure 2. Talent components

\subsection{How to group talent. Talent pools as a configuration}

As a result of the identification of talent derived from the cases analysed, we can conclude that the configurational approach (Doty, Glick \& Huber, 1993; Meyer, Tsui \& Hinings, 1993; Delery \& Doty, 1996) constitutes the best theoretical framework for understanding the grouping of talent in organisations.

Our cases show that talent can be considered as integrated into different configurations, complying with the conditions of creation, differentiation and equifinality. 
With respect to the creation of configurations, different types can be found in organisations that are formed either by exogenous or endogenous forces. In the former, the coercive, regulatory and mimetic pressure appears to result in an isomorphism in the four companies analysed, with respect to the definition and identification of the same talent configurations. In the latter, the endogenous forces may cause a cognitive process to create structures and, in our case, the existence of people with talent leading to a differentiation of the workforce in different configurations.

The employees considered as talent in each of the configurations identified, or talent pools, share a common feature: they have a proven high performance and future potential, albeit without a consistent profile with respect to capacity, knowledge or experience, or with respect to the level of responsibility of their hierarchical functions.

Secondly, in relation to differentiation, the configurational approach defines organisational configurations as "multidimensional constellations of different conceptual features that commonly appear together" (Meyer et al., 1993:1175). As suggested previously by certain authors, in our cases we identified three different configurations of talent or talent pools. Accordingly, Björkman and Smale (2010) have identified three groups of talent: a pool for senior managers, one for intermediate managers, and another one for people at the start of their career. Mäkelä et al. (2010), in turn, have made a distinction between senior positions, top potentials, and potentials.

According to the configurational approach, different TM tools or practices are developed in each configuration to better achieve objectives (horizontal adjustment) for more efficient TM and to achieve the strategic objectives established by the talent strategy (vertical adjustment).

Thirdly, the principle of equifinality is present in the configurations, according to which a system can reach the same end result with different initial conditions and in a variety of ways (Doty et al., 1993). Accordingly, the three ideal talent pool configurations identified cater for the proposed objective of guaranteeing future strategic positions, although with different employees, different practices, and at different times. The fact that some talented employees hold management positions means they have a shorter path to reach strategic positions within the company than others that do not, given that although possessing talent implies a high likelihood of future promotion, the progress towards key or strategic management levels in the company's future will take place gradually over time.

For these reasons, we identified three talent configurations, which we call talent pools 1, 2 and 3, which must be managed differently (Figure 2). Firstly, Talent pool 1 is comprised of employees with talent that hold executive management positions. Secondly, Talent pool 2 is comprised of employees that hold mid-management positions. Thirdly, talent pool 3 is comprised of employees that do not hold management positions.

The first two configurations (C1 and C2) represent people with talent that hold management positions (executive and mid-management) at the company. They are highly valuable to the organisation and its future strategy, and they have to be involved in TM. Given their value, an investment is required because they are of extraordinary value for the company's competitive advantage in the future. The TM objective for both configurations is to develop these people for strategic positions in the future.

Finally, the third configuration (C3) is comprised of people with talent that do not hold management positions within the company (Talent pool 3), although they do hold key positions, meaning that the identification of talent is essential for the company to locate it for future development, to avoid losing it, and to guarantee the succession of management positions. The TM objective in this case would be to locate this talent, as such persons do not hold management positions and their talent could therefore be spread throughout the organisation.

Based on the above, we propose the following (Figure 3):

Proposition 2. TM requires the identification of three types of talent pools for the application of differentiated practices in talent development. 
Proposition 2.1. Talent pool 1 is comprised of talented employees holding top management positions that develop their talent within a period of less than three years.

Proposition 2.2. Talent pool 2 is comprised of talented employees holding mid-management positions that develop their talent within a period of 3 to 5 years.

Proposition 2.3. Talent pool 3 is comprised of employees that do not hold management positions and develop their talent in a period of time exceeding 5 years.

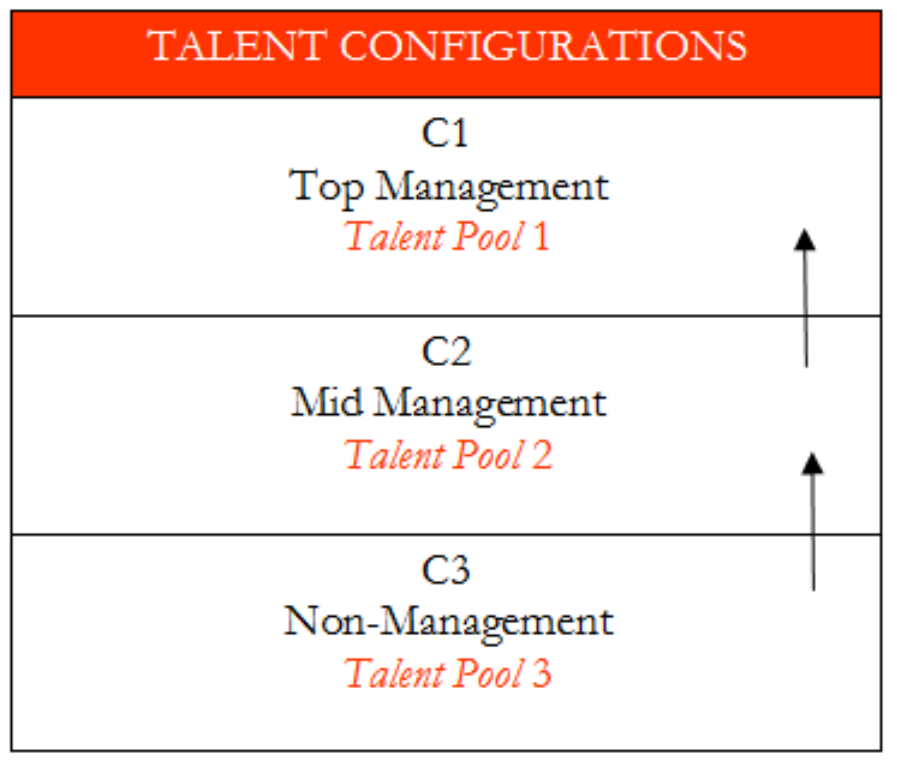

Figure 3. Talent as a configuration

\section{Conclusions}

Although talent is deemed to be intangible capital that adds value to organisations (Alonso \& Garcia-Muiña, 2014), there are few studies in the literature that address the process of identifying and locating talent. establishing the components of talent for its identification and location underpins this paper. Our initial conclusion accordingly is that from a corporate perspective talent involves people, and that tm focuses solely on the part of talent that can be developed.

This means that nurturing talent development is vital for companies. We propose the configurational approach as a theoretical framework for grouping talent into different configurations or talent pools. Our second conclusion is that talent may be found anywhere in an organisation, in management positions or not, and its grouping is crucial for its differentiated development in terms of both the tools and the time required to do so, depending on the talent pool involved.

Some contributions and implications can be derived for academics and practitioners. For academics, on the one hand, a theoretical framework is proposed (as called for by Thunnissen et al. 2013b): the configurational approach for grouping talent into different configurations or talent pools for the application of differentiated development policies. On the other hand, an empirical study is provided in a field dominated by theoretical analyses (Nijs et al., 2014) and, in a Spanish context, where there have been very few publications to date (VivasLópez et al., 2011; Valverde et al., 2013; Vivas-López, 2014; Maqueira et al., 2019)

From the perspective of practitioners, this work's contribution consists of different configurations of talent pools for the design and implementation of a series of TM practices that are different for each configuration, thus allowing companies to develop talent at different points in time to achieve their future strategic objectives. 
In this regard, companies can be more aware that talent has become a determining factor of competitiveness, and through efficient TM they can restructure the knowledge, experience and the commitment of those employees that contribute the most to the company's future, and build competitive advantages that are sustainable in the long term.

\section{Declaration of Conflicting Interests}

The authors declared no potential conflicts of interest with respect to the research, authorship, and/or publication of this article.

\section{Funding}

The authors received no financial support for the research, authorship, and/or publication of this article.

\section{References}

Al Ariss, A., Cascio, W. F., \& Paauwe, J. (2014). Talent Management: Current theories and future research direction. Journal of World Business, 49(2), 173-179. https://doi.org/10.1016/j.jwb.2013.11.001

Alonso, A., \& García Muiña, F.E. (2014). La gestión del talento: Líneas de trabajo y procesos clave. Intangible Capital, 10(5), 1003-1025.

BCG (2018). A CEO's Guide to Talent Management Today. Retrieved from: https://www.bcg.com/publications/2018/ceo-guide-talent-management-todav.aspx

Björkman, I., \& Smale, A. (2010). La gestión global del talento: Retos y Soluciones. Universia Business Review, 27, $28-41$.

Boudreau, J.W., \& Ramstad, P.M. (2005). Talentship, talent segmentation, and sustainability: A new HR decision science paradigm for a new strategy definition. Human Resource Management, 44(2), 129-136. https://doi.org/10.1002/hrm.20054

Chami-Malaeb, R., \& Garavan, T. (2013). Talent and leadership development practices as drivers of intention to stay in Lebanese organisations: the mediating role of affective commitment. The International Journal of Human Resource Management, 24(21), 4046-4062. https://doi.org/10.1080/09585192.2013.789445

Cheese, P., Thomas, R.T., \& Craig, E. (2008). The talent powered organization: Strategies for globalization, talent management and high performance. London: Kogan Page.

Chuai, X., Preece, D., \& Iles, P. (2008). Is talent management just “old wine in new bottles"?: The case of multinational companies in Beijing. Management Research News, 31(12), 901-911. https://doi.org/10.1108/01409170810920611

Collings, D.G., \& Mellahi, K. (2009). Strategic talent management: A review and research agenda. Human Resource Management Review, 19, 304-313. https://doi.org/10.1016/j.hrmr.2009.04.001

Collings, D.G., \& Mellahi, K. (2013). Commentary on: “Talent-Innate or acquired? Theoretical considerations and their implications for talent management. Human Resource Management Review, 23(4), 322-325. https://doi.org/10.1016/j.hrmr.2013.08.003

Collings, D.G., Scullion, H., \& Vaiman, V. (2015). Talent management: Progress and prospects. Human Resource Management Review, 25, 233-235. https://doi.org/10.1016/j.hrmr.2015.04.005

Delery, J.E., \& Doty, D.H. (1996). Modes of theorizing in strategic human resource management: Tests of universalistic, contingency, and configurational performance predictions. Academy of Management Journal, 39(4), 802-835. https://doi.org/10.5465/256713

Deloitte (2015). Talent management in a new area. Retrieved from: https://www2.deloitte.com/content/dam/Deloitte/lu/Documents/humancapital/lu en talent-management-newarea 122015.pdf 
Doty, D., Glick, W., \& Huber, G. (1993). Fit, equifinality and organizational effectiveness: A test of two configurational theories. Academy of Management Journal, 36(6), 1196-1250. https://doi.org/10.2307/256810

Dries, N. (2013). The psychology of talent management: A review and research agenda. Human Resource Management Review, 23(4), 272-285. https://doi.org/10.1016/j.hrmr.2013.05.001

Dries, N., Van Acker, F., \& Verbruggen, M. (2012). How ‘boundaryless' are the careers of high potentials, key experts and average performers?. Journal of Vocational Behavior, 81(2), 271-279. https://doi.org/10.1016/j.jvb.2011.10.006

Eisenhardt, K.M. (1989). Building Theories from Case Study Research. Academy of Management Review, 14(4), 532-550. https://doi.org/10.5465/amr.1989.4308385

Farndale, E., Scullion, H., \& Sparrow, P. (2010). The role of the corporate HR function in global talent management. Journal of world business, 45(2), 161-168. https://doi.org/10.1016/j.jwb.2009.09.012

Gallardo-Gallardo, E., Dries, N., \& González-Cruz, T. (2013). What is the meaning of 'talent' in the world of work?. Human Resource Management Review, 23, 290-300. https://doi.org/10.1016/j.hrmr.2013.05.002

Gallardo-Gallardo, E., Nijs, S., Dries, N., \& Gallo, P. (2015). Towards an understanding of talent management as a phenomenon-driven field using bibliometric and content analysis. Human Resource Management Review, 25, 264-279. https://doi.org/10.1016/j.hrmr.2015.04.003

Gallardo-Gallardo, E., \& Thunnissen, M. (2016). Standing on the shoulders of giants? A critical review of empirical talent management research. Employee Relations, 38(1), 31-56. https://doi.org/10.1108/ER-10-2015-0194

Ganz, J. (2006). Talent development: The architecture of a talent pipeline that works. Ivey Business Journal, 1, 1-4.

Garavan, T.N., Carbery, R., \& Rock, A. (2012). Mapping talent development: Definition, scope and architecture. European Journal of Training and Development, 36(1), 5-24.

https://doi.org/10.1108/03090591211192601

Huselid, M.A., Beatty, R.W., \& Becker, B.E. (2005). A players' or 'A positions'?. Harvard Business Review, 83(12), $110-117$

Iles, P., Chuai, X., \& Preece, D. (2010a). Talent Management and HRM in Multinational companies in Beijing: Definitions, differences and drivers. Journal of World Business, 45, 179-189. https://doi.org/10.1016/j.jwb.2009.09.014

Iles, P., Preece, D., \& Chuai, X. (2010b). Talent management as a management fashion in HRD: Towards a research agenda. Human Resource Development International, 13(2), 125-145. https://doi.org/10.1080/13678861003703666

Lewis, R.E., Heckman, R.J. (2006). Talent management: A critical review. Human Resource Management Review, 16(2), 139-154. https://doi.org/10.1016/j.hrmr.2006.03.001

Mäkelä, K., Björkman, I., \& Ehrnrooth, M. (2010). How do MNCs establish their talent pools? Influences on individuals' likelihood of being labeled as talent. Journal of World Business, 45(2), 134-142. https://doi.org/10.1016/j.jwb.2009.09.020

Makram, H., Sparrow, P., \& Greasley, K. (2017). How do strategic actors think about the value of talent management? Moving from talent practice to the practice of talent. Journal of Organizational Effectiveness: People and Performance, 4(4), 259-378. https://doi.org/10.1108/JOEPP-06-2017-0051

Maqueira, J.M., Bruque, S., \& Uhrin, Á. (2019). Talent management: Two pathways to glory? Lessons from the sports arena. Employee Relations, 41(1), 34-51. https://doi.org/10.1108/ER-11-2017-0271

McDonnell, A., Collings, D.G., Mellahi, K., \& Schuler, R. (2017). Talent management: A systematic review and future prospects. European Journal of International Management, 11(1), 86-128.

https://doi.org/10.1504/EJIM.2017.081253 
Meyer, A.D., Tsui, A.S., \& Hinings, C.R. (1993). Configurational approaches to organizational analysis. Academy of Management Journal, 36(6), 1175-1195. https://doi.org/10.2307/256809

Meyers, M.C., \& Van Woerkom, M. (2014). The influence of underlying philosophies on talent management: Theory, implications for practice, and research agenda. Journal of World Business, 49(2), 192-203. https://doi.org/10.1016/j.jwb.2013.11.003

Meyers, M.C., Van Woerkom, M., \& Dries, N. (2013). Talent-Innate or acquired? Theoretical considerations and their implications for talent management. Human Resource Management Review, 23(4), 305-321. https://doi.org/10.1016/j.hrmr.2013.05.003

Nijs, S., Gallardo-Gallardo, E., Dries, N., \& Sels, L. (2014). A multidisciplinary review into the definition, operationalization, and measurement of talent. Journal of World Business, 49, 180-191. https://doi.org/10.1016/j.jwb.2013.11.002

Nilsson, S., \& Ellström, P.E. (2012). Employability and talent management: challenges for HRD practices. European Journal of Training and Development, 36(1), 26-45. https://doi.org/10.1108/03090591211192610

Ross, S. (2013). How definitions of talent suppress talent management. Industrial and Commercial Training, 45(3), 166-170. https://doi.org/10.1108/00197851311320586

Schuler, R.S., Jackson, S.E., \& Tarique, I. (2011). Global talent management and global talent challenges: Strategic opportunities for IHRM. Journal of World Business, 46(4), 506-516. https://doi.org/10.1016/j.jwb.2010.10.011

Shulga, L.V., \& Busser, J.A. (2019). Talent management meta review: a validity network schema approach. International Journal of Contemporary Hospitality Management, 31 (10), 3943-3969. https://doi.org/10.1108/IJCHM10-2018-0876

Silzer, R., \& Church, A.H. (2009). The pearls and perils of identifying potential. Industrial and Organizational Psychology, 2, 377-412. https://doi.org/10.1111/j.1754-9434.2009.01163.x

Silzer, R., \& Dowell, B.E. (2010). Strategy-Driven Talent Management. A leadership imperative. San Francisco: John Wiley \& Sons.

Stahl, G., Björkman, I., Farndale, E., Morris, S.S., Paauwe, J., Stiles, P., et al. (2012). Six principles of effective global talent management. Sloan Management Review, 53(2), 25-42.

Sparrow, P. (2019). A historical analysis of critiques in the talent management debate. BRQ Business Research Quarterly, 22(3), 160-170. https://doi.org/10.1016/j.brq.2019.05.001

Sparrow, P.R., \& Makram, H. (2015). What is the value of talent management? Building value-driven processes within a talent management architecture. Human Resource Management Review, 25(3), 233-328. https://doi.org/10.1016/j.hrmr.2015.04.002

Tansley, C. (2011). What do we mean by the term "talent" in talent management?. Industrial and Commercial Training, 43(5), 266-274. https://doi.org/10.1108/00197851111145853

Tansley, C., Turner, P., Carley, F., Harris, L., Sempik, A., \& Stewart, J. (2007). Talent: Strategy, management, measurement. London: Chartered Institute of Personnel and Development (CIPD).

Thunnissen, M., Boselie, P., \& Fruytier, B. (2013a). A review of talent management: 'infancy or adolescence?'. The International Journal of Human Resource Management, 24(9), 1744-1761. https://doi.org/10.1080/09585192.2013.777543

Thunnissen, M., Boselie, P., \& Fruytier, B. (2013b). Talent management and the relevance of context: Towards a pluralistic approach. Human Resource Management Review, 23(4), 326-336. https://doi.org/10.1016/j.hrmr.2013.05.004

Thunnissen, M., \& Gallardo-Gallardo, E. (2019). Rigor and relevance in empirical TM research: Key issues and challenges. BRQ Business Research Quarterly, 22(3), 171-180. https://doi.org/10.1016/j.brq.2019.04.003 
Thunnissen, M., \& Van Arensbergen, P. (2015). A multi-dimensional approach to talent: An empirical analysis of the definition of talent in Dutch academia. Personnel Review, 44 (2), 182-199. https://doi.org/10.1108/PR-102013-0190

Valverde, M., Scullion, H., \& Ryan, G. (2013). Talent management in Spanish medium-sized organisations. The International Journal of Human Resource Management, 24(3), 1832-1852. https://doi.org/10.1080/09585192.2013.777545

Vivas-López, S. (2014). Talent Management and Teamwork Interaction: Evidence in Large Spanish Companies. International Journal of Business, 19(1), 30.

Vivas-López, S., Peris-Ortiz, M., \& Rueda-Armengot, C. (2011). Managing talent for organisational learning. European Journal of International Management, 5(5), 540-557. https://doi.org/10.1504/EJIM.2011.042178

Yin, R.K. (1994). Case Study Research Design and Methods, Applied Social Research Methods Series (Vol.5, Second Edition). London: Sage Publications.

Intangible Capital, 2021 (www.intangiblecapital.org)

\section{(c) (1) $\$$}

Article's contents are provided on an Attribution-Non Commercial 4.0 Creative commons International License. Readers are allowed to copy, distribute and communicate article's contents, provided the author's and Intangible Capital's names are included. It must not be used for commercial purposes. To see the complete license contents, please visit https://creativecommons.org/licenses/by-nc/4.0/. 